\title{
Música e Vida Pastoril na Grécia antiga: o contexto ático segundo evidências arqueológicas, iconográficas e literárias
}

\author{
Fábio Vergara Cerqueira*
}

\begin{abstract}
CERQUEIRA, F.V. Música e Vida Pastoril na Grécia antiga: o contexto ático segundo evidências arqueológicas, iconográficas e literárias. Revista do Museu de Arqueologia e Etnologia, São Paulo, 18: 199-210, 2008.
\end{abstract}

Resumo: Este estudo visa a interpretar, por meio do cotejamento entre os registros literários, visuais e materiais, as características e sentido da presença da atividade musical na vida pastoril da Grécia antiga e, em particular, do ambiente cultural e social ático.

Palavras-chave: Grécia Antiga - Música - Iconografia - Rural.

\section{Introdução}

$\mathrm{E}$ ste estudo visa a interpretar, por meio do cotejamento entre os registros literários, visuais e materiais, as características e sentido da presença da atividade musical na vida pastoril da Grécia antiga e, em particular, do ambiente cultural e social ático.

Constata-se um relativo silêncio quanto ao mundo rural, sobretudo com relação à pecuária e pastoreio, no que tange ao registro da iconografia dos vasos áticos do período arcaico e clássico (séc. VI a IV a.C), contrariamente à abundância de testemunhos literários gregos antigos.

\section{Mundo rural e sua representação iconográfica e literária}

A quantificação dos dados referentes à pintura vascular ática, atinentes a cenas de vida

(*) Departamento de História e Antropologia; Laboratório de Antropologia e Arqueologia do Instituto de Ciências Humanas da Universidade Federal de Pelotas-UFPEL. fabiovergara@uol.com.br diária, revela acentuada desproporção entre o material iconográfico concernente à música no mundo rural e aquele concernente a esferas da vida urbana: em nosso levantamento, as cenas rurais não atingem $1 \%$, em um universo de mais de mil registros iconográficos. (Cerqueira 2001:421; 2007).

A inferioridade numérica dos testemunhos imagéticos da música no mundo rural insere-se em um fenômeno global na cultura ateniense do quinto e quarto século. Conforme Chevitarese (2001:197-8), "constata-se uma drástica redução das cenas envolvendo o mundo rural nos vasos áticos de figuras vermelhas, a partir da segunda metade do quinto século, chegando mesmo a praticamente desaparecer no século seguinte." A avaliação quantitativa elaborada por esse autor revela que "a temática rural é apreciada por um número muito restrito de indivíduos no período clássico". Deste modo, na Atenas clássica, diferentemente do que se constata em outras áreas geográficas do mundo helenístico, tanto pintores quanto autores se desinteressaram pelo campo, na medida em que nos passam tão-somente uma visão fragmentada e preconceituosa da khorá, tratando os camponeses como "ignorantes 
Música e Vida Pastoril na Grécia antiga: o contexto ático segundo evidências arqueológicas, iconográficas e literárias. Revista do Museu de Arqueologia e Etnologia, São Paulo, 18: 199-210, 2008.

politicos e incapazes de serem sociáveis" (Burford 1993:10. Cf. Aristófanes Vespas 1120-1537; Os Acarnenses 33-39; As Nuvens 43-52, 372. Aristóteles Política 1328b, 1329a e 1330a. Teofrasto Os caracteres 4.7-8, 4.11-2, 4.16).

$\mathrm{O}$ autor, de forma convincente, interpreta que há uma relação entre o fato de as fontes históricas e iconográficas do período clássico esconderem o rural e a constituição, contemporaneamente, da hegemonia ateniense sobre o Egeu, conquistada nos anos que se seguiram às Guerras Pérsicas. Essa Atenas dominante e cosmopolita, que exercia uma preponderância internacional do ponto de vista sócio-político, econômico, ideológico e cultural, não queria ser vista como uma pólis rural. Assim, preferiam vincular a imagem da cidade às atividades que transcorriam no espaço urbano, sobretudo a política.

Todavia, apesar deste preconceito e desdém pelo mundo rural, revelado pelos atores sociais que produziram a maior parte dos testemunhos remanescentes desta sociedade - testemunhos escritos ou visuais -, a vida rural desempenhava um papel de extrema relevância na vida ática, sobretudo no aspecto econômico e demográfico, como demonstram as evidências arqueológicas, nada obstante a pujança do artesanato urbano, representado inclusive pela cerâmica, portadora dessa imagética que oculta o universo rural.

Dessa forma, para conseguirmos reconstituir as práticas musicais da vida campesina, precisamos romper a barreira do silêncio imposta ao campesinato, que não usufruía de veículos literários para expressar a representação que fazia de si mesmo.

Quanto aos seis vasos incorporados ao nosso catálogo de estudo das representações de cenas musicais de vida diária na cerâmica ática, há que se ressaltar que somente dois retratam cenas humanas (Fig. 2, Fig. 2.1. Cerqueira 2001: cat. 525, 525.1), o restante apresentando alusões mitológicas a práticas cotidianas rurais. Os registros iconográficos da cultura musical no ambiente rural, na pintura vascular ática, concentram-se em duas atividades econômicas: a agricultura, especificamente a viticultura, e o pastoreio. É interessante, aqui, lembrar algumas particularidades: as cenas com vindima, restritas à técnica de figuras negras (séc. VI), retratam as situações específicas em que a música do aulós se faz presente nesta atividade (Cerqueira 2007), acompanhando a colheita e o pisoteio das uvas; as cenas que relacionam a música com a vida do pastor fazem tão-somente alusão à sua presença neste contexto social, não a retratando no curso da atividade econômica pastoril.

Para superarmos esse quase silêncio ateniense sobre o tipo de música praticada no campo no período clássico, precisamos recorrer à comparação, considerando que Atenas não constitui um fenômeno isolado nos costumes da vida rural e na cultura musical grega antiga. Mesmo possuindo suas especificidades, a Atenas clássica compartilha aspectos em comum com outras regiões e até mesmo outros períodos do mundo grego antigo. Precisamos ter em mente que, quando falamos de campo, lidamos com o que se chama em história de longue durée. Na vida rural, as mudanças são mais lentas e as continuidades mais longevas (Cerqueira 2007).

Desse modo, buscaremos recorrer a referências de outras regiões e de outras épocas, bem como à diversidade de registros textuais, materiais e visuais, para explicar e compensar as poucas evidências que a iconografia ática nos fornece sobre a música na vida rural. Nesse panorama mais amplo, visitando inclusive o imaginário mitológico, encontramos testemunhos altamente sugestivos e, em certos casos, irrefutáveis, sobre o uso da música no acompanhamento das lides agro-pastoris.

Como colocado acima, as evidências iconográficas da cultura musical na esfera rural concentram-se nas temáticas da viticultura e pastoreio. As cenas de vindima e pisoteio de uva foram analisadas em artigo de nossa autoria, recentemente publicado: "O uso da música no trabalho rural na Antigüidade clássica: o caso do aulós na vindima" (Cerqueira 2007: 243-257). Dedicamo-nos, aqui, de forma a complementar o estudo da música na esfera rural, a aprofundar a análise sobre a presença da música na vida pastoril.

\section{Música e Pastoreio}

A vida pastoril aparece de forma extremamente discreta na iconografia ática, sendo quase 
completamente oclusa do repertório dos pintores de figuras vermelhas. Conforme os dados levantados por Chevitarese, referentes aos vasos áticos de figuras vermelhas, para um total de 103 inventariados com cenas rurais, apenas três registram cenas de pastoreio, contra 16 cenas de pisoteio de uvas e 62 cenas de caça. (Chevitarese 2001:198, tabela 26.) Isso mostra o desinteresse dos artistas em associar seus produtos ao universo rudimentar dos pastores, pois isso poderia dificultar inclusive a venda de seus vasos, voltada ao mercado urbano.

A conseqüência dessa visão preconceituosa dos citadinos atenienses, relativamente à vida da khorá ática, reverbera modernamente no pouco interesse entre os historiadores modernos em estudar a iconografia do pastor. Nesse sentido, as pesquisas de M.C. Amouretti (1979) e A.L. Chevitarese (2000) adquirem muita importância.

Em sua investigação sobre a iconografia do pastor, Amouretti identifica séries iconográficas bastante dispersas no tempo e no espaço. Para o período abrangido em nosso estudo, marcado pela cerâmica ática de figuras negras e vermelhas (da metade do séc. VI à virada do séc. V para o IV), encontra três focos de produção iconográfica no Mediterrâneo: trata-se de pequenas estátuas de exvoto, muitas delas de bronze, encontradas em santuários ligados a Pã ou a Hermes kriophóros, localizados na Arcádia (no Monte Liceu), em Creta (como em Kato Symi) e na Beócia. Em nenhum desses santuários, as imagens votivas do pastor estão associadas a algum instrumento musical, não obstante a tipificação desses, na literatura, como um atributo pastoril. A syrinx aparece como atributo iconográfico do pastor somente em estátuas produzidas pelos ateliês do norte, entre a metade do séc. IV e o séc. II a.C. Em Anfípolis, encontram-se muitas estátuas do jovem pastor, com boné frígio, sy̆rinx, cajado, às vezes um cachorro ou uma ovelha. (Amouretti 1979:156-157)

No que tange à cerâmica ática, o desinteresse dos pintores é mais acentuado ainda entre aqueles da técnica de figuras negras, pois não se encontra um único exemplo de pastor no período arcaico, apesar do grande número de mitos, concernentes, sobretudo à juventude de heróis recolhidos e educados por pastores (Édipo, Ânfion, Páris). A princípio, pode-se afirmar que a iconografia ática, quando retratava o mundo rural, inspirava-se principalmente nos temas ligados ao vinho. Isso, porém, não justifica a oclusão do universo pastoril, sobretudo se considerarmos sua valorização simbólica nas narrativas míticas referentes à educação dos heróis na lýra, narrativas nas quais a reclusão entre os pastores e o aprendizado da lýra aparecem como uma espécie de ritual de passagem desses heróis. Esse desinteresse pelo pastor deve-se ligar à visão negativa que se passava entre os citadinos sobre o tipo rural, caracterizado, como identifica Chevitarese, como grosseiro, ignorante, desprovido de refinamento social e avesso à política, devendo ser visto mais como escravo do que como cidadão. (Chevitarese 2000:1. Cf. Aristófanes Vespas 1120-1537; Os Acarnenses 33-39; As Nuvens 43-52, 372. Aristóteles Politica 1328b, 1329a e 1330a. Teofrasto Os caracteres 4.7-8, 4.11-2, 4.16).

No fundo mítico, verifica-se a importância que a música devia ocupar na representação do pastor: por exemplo, Páris e Ânfion, salvos de seu desígnio maldito e educados por pastores, escondendo-se nas montanhas, como jovens pastores, e lá tocando lýra. Efetivamente, no séc. V elabora-se um tipo iconográfico do jovem pastor músico (Amouretti 1979:158-159). Essa pequena série iconográfica mistura representações mitológicas e humanas.

Os mitos respeitantes ao período de crescimento e educação de Páris, escondido nas montanhas e tocando lýra, encontram ressonância na imagética ática, sobretudo nas representações do julgamento de Páris: é comum a imagem do herói troiano, adolescente, sentado sobre um rochedo, tocando lýra, rodeado por animais, enquanto Hermes interrompe seu sossego pastoril, trazendo-lhe Hera, Atena e Afrodite, para que o rapaz decida qual delas é a mais bela. Um bom exemplo encontra-se sobre uma hydría de figuras vermelhas, do Museu Britânico, datada do terceiro quartel do quinto século (Fig. 1. Cerqueira 2001: cat. 526): Páris, vestindo um manto rústico, descansa sentado sobre uma base rochosa, ao lado da qual se vê uma ovelha. Outro vaso (Fig. 1.1. Cerqueira 2001: cat. 526.1) apresenta uma variação: em situação semelhante, o mesmo está rodeado por cabras. 
Música e Vida Pastoril na Grécia antiga: o contexto ático segundo evidências arqueológicas, iconográficas e literárias. Revista do Museu de Arqueologia e Etnologia, São Paulo, 18: 199-210, 2008.

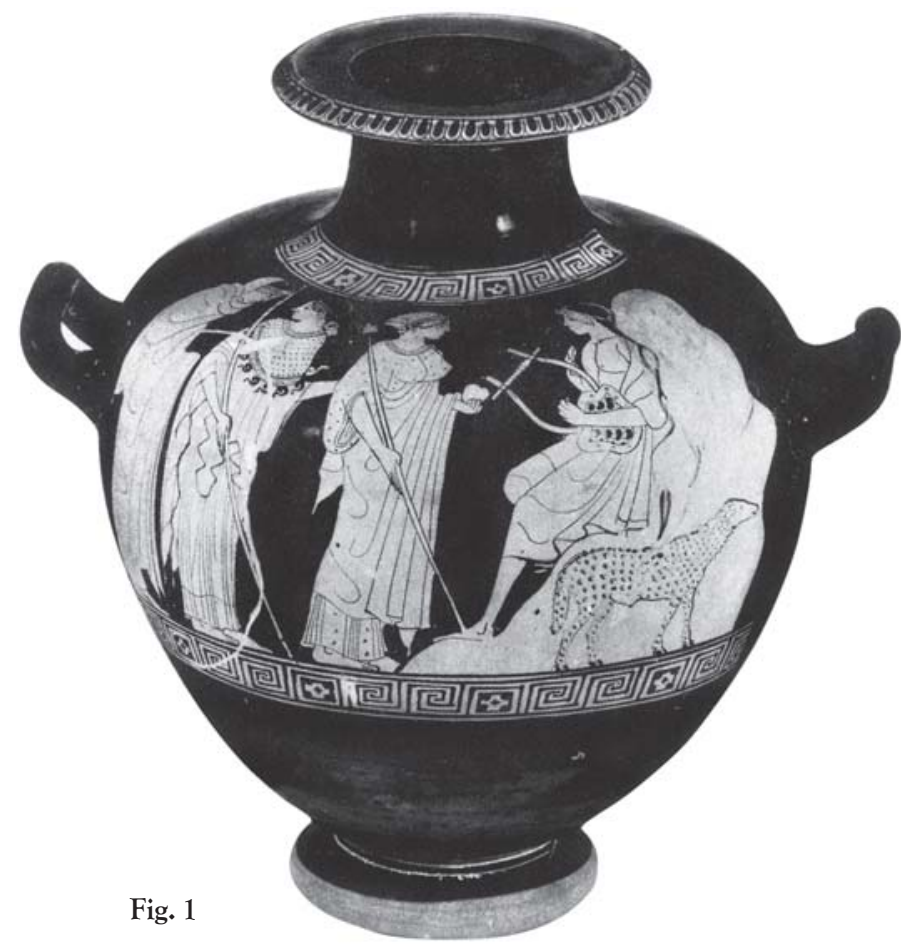

Segundo diferentes narrativas míticas, vários heróis teriam recebido a lýra de Hermes, que em alguns casos teria sido o próprio professor, num contexto em que esses heróis-alunos eram caracterizados como pastores. Em muitos casos, Hermes ou o pastor ou o professor de lýra estabelecem laços amorosos com o heróialuno, simbologia que poderia ter prestado muito bem ao elogio à pederastia, tão comum na iconografia e nos textos do quinto século. Esse é o caso de Ânfion, que recebe a lýra de Hermes como presente por seu amor (Filostratos Imagens I.10). Porém, não lhe bastava ser seu amante, sendo também o professor de música de Ânfion (Pausânias IX.5.8). Apesar dessa conotação pedagógica da pederastia, inerente ao ensino pastoril da lýra por Hermes, os pintores preferiram colocar, como metáfora elogiosa da pederastia, as abordagens de Eos a Títhonos, evitando representações do pastor-amante-professor de música. ${ }^{2}$

No período clássico, já havia se disseminado a idéia de Ânfion como precursor da lýra (Platão Leis III.677d), a qual aprendera durante seu retiro nas montanhas, protegido pelos pastores. Apesar de sua assimilação pela cultura intelectual urbana, a lembrança da lýra como instrumento originariamente pastoril permaneceu ao longo de toda Antigüidade clássica. No relato de um autor romano da época imperial, Antonius Liberalis, a invenção da lýra é atribuída a um pastor: Cerambos, filho de Euseiros (filho do próprio Poseidon) e de Eidothéia (uma ninfa), habi-

(2) A mesma relação pedagógico-amorosa une Pã e Dáfnis: do seu amante, o jovem pastor aprende a tocar a sy̆rinx. Cf. Antologia grega. Epigramas descritivos (IX), 341. "Dafnis e Pã." (Glaucos de Nicópolis ou de Atenas, atribuição incerta). 
tando região montanhosa e cuidando de grandes rebanhos, foi o melhor cantor de seu tempo, celebrado pelos cantos bucólicos; vivendo nas montanhas, inventou a syrinx dos pastores e foi o primeiro mortal a tocar a lýra, compondo uma grande quantidade de canções muito belas (Antonius Liberalis As metamorfoses 23.1-2).

Vemos que esse autor tardio coloca, lado a lado, a lýra e a sy̆rinx como instrumentos pastoris. Nesse ponto, está bebendo das tradições literárias mais antigas e, provavelmente, traduzindo uma realidade musical campesina. No Hino homérico a Hermes, aprendemos que este, após dar a lýra como presente a Apolo, retira-se para pastorear o gado nos pastos e montanhas; sem a lýra, no entanto, encontrou habilidade para inventar outra arte, criando o som das syringes (Hino homérico a Hermes 490sq, 511. Cf. Epigramas funerários [VII]. Antologia palatina 657 [Leônidas de Tarento, III a.C., coroa de Meleagro]). O hino, um dos mais tardios entre os hinos homéricos, parece refletir uma situação histórica concreta: (i) a assimilação da lýra pela cultura citadina, na qual se tornará referência icônica da paideía, acontecimento cultural simbolizado pela adoção desse instrumento por Apolo, e, ao mesmo tempo, (ii) a disponibilidade de um instrumento especial para os pastores, a sy̆rinx, que não foi assimilada pela vida urbana ateniense, motivo pelo qual sua representação é bastante escassa na pintura de vasos áticos. Não obstante tudo o que se fala da idealizada unidade entre o urbano e o rural na cidadeEstado grega, ${ }^{3}$ a iconografia do pastor parece indicar uma profunda cisão cultural entre essas duas esferas, a qual devia traduzir inclusive rivalidades.

(3) Gernet (1982[1968]: 266-78) mostra como o direito grego não prevê diferenciação entre o elemento urbano e o rural, inclusive por que a condição de cidadão estava bastante ligada à posse da terra; além disso, a ideologia políade valorizava mais o trabalho da terra, tido como nobre, do que os artesanatos e o comércio urbanos.
Uma longa tradição da Antigüidade caracteriza a syrinx como o instrumento musical dos pastores. Essa tradição remonta ao livro XVIII da Ilíada, datável do séc. VIII: Homero fala-nos de dois pastores que comandam o rebanho tocando a syrinx (Homero Ilíada XVIII.525sq). Segundo Calímaco, a invenção da sy̆rinx seria anterior à do aulós (Calímaco Hino a Ártemis 242-5), sugerindo sua antigüidade entre os gregos, sobretudo na Arcádia. Bíon (ap. 100 a.C.), poeta bucólico tributário do estilo de Teócrito, afirmava que um pastor devia fabricar ele mesmo a sua sy̆rinx, não precisando recorrer a nenhum artesão, pois se tratava, segundo ele, de um trabalho bastante fácil. Devia ele mesmo ter esse costume, pois a syrinx era o seu instrumento, como revela o comovente canto fúnebre que um aluno seu the dedicou (Moschos Canto fúnebre em honra de Bion 52-6):

"Quem tocará tua sy̆rinx? ... Quem colocará a boca sobre teus caniços?... Eles ainda respiram teus lábios e teu sopro; nos tubos erra ainda o eco do teu canto.

Levarei a Pã o instrumento melodioso?

Talvez ele mesmo relutará em pousar seus lábios no teu instrumento, na crença de ser inferior a ti." 4

No séc. IV, um dos motivos que alimentavam o desprezo de Aristóxenes pelo aulós e pela sy̆rinx era o fato de que os pastores aprendiam a tocar esses instrumentos sem precisar de um professor, motivo pelo qual os considerava instrumentos muito banais (Aristóxenes ap. Ateneu IV.174e-f). Nos tempos de Aristóxenes, a confiarmos na tradição que nos informa Ateneu, o aulós constituía uma alternativa como instrumento pastoril. Com efeito, preservaram-se dois vasos áticos de figuras vermelhas, datados do séc. V, em que o pastor é associado ao aulós (Fig. 2, Fig. 2.1).

(4) Tradicionalmente atribuído a Moschus, deve ser de um autor inferior, pois Bíon lhe é posterior, sendo inverossímil que compusesse um canto fúnebre para ele. Deve ser de autoria de um discípulo. 
Música e Vida Pastoril na Grécia antiga: o contexto ático segundo evidências arqueológicas, iconográficas e literárias. Revista do Museu de Arqueologia e Etnologia, São Paulo, 18: 199-210, 2008.

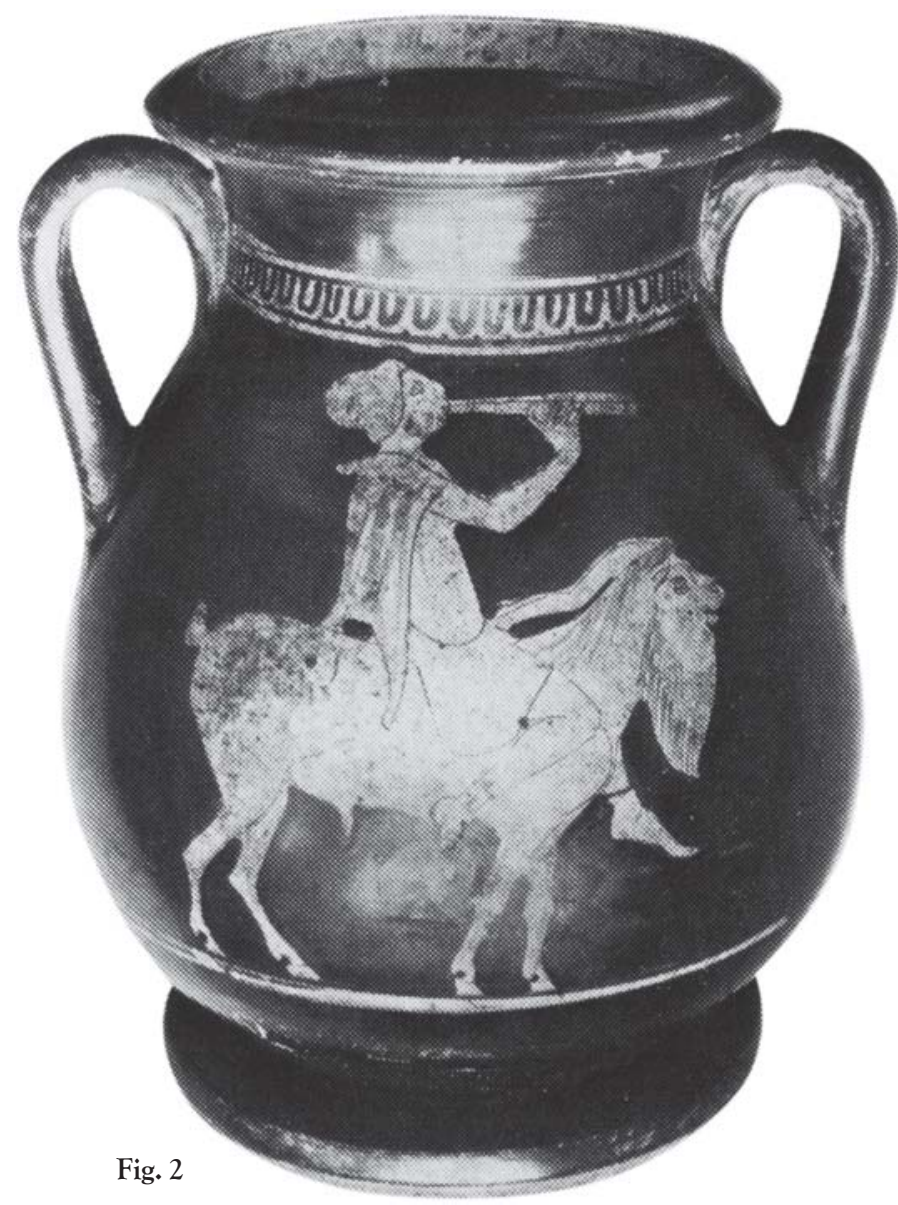

Sobre a peliké de Paris (Fig. 2), encontramos a caracterização típica do pastor: gorro (pîlos), túnica curta (clâmide) e pele de animal jogada como manto. Trata-se de um jovem, sentado sobre um animal. Como o pintor repete a cena dos dois lados do vaso, num lado, o vemos sobre um bode, no outro, sobre um carneiro. $\mathrm{O}$ Pintor de Geras registrou o que Amouretti chama de "tipo iconográfico do jovem pastor músico": sobre os dois lados do vaso, o pastor está soprando aulós. No segundo vaso, uma ânfora de Berlim (Fig. 2.1), o jovem pastor está sentado sobre uma base rochosa, do mesmo modo como os pintores costumam representar Páris com sua lýra (Fig. 1, Fig. 1.1): porém, diferentemente de Páris, está soprando um aulós. A particularidade desse vaso é a companhia de um sátiro. Ora, trata-se de um acompanhante previsível, se lembrarmos da conotação rural e naturalista da origem dos cultos dionisíacos; lembremos também que Pã, o pastor músico por excelência, foi convidado por Dioniso para diverti-lo durante seus festejos em companhia de mênades e silenos. Essa deve ser a situação insinuada na ânfora de Berlim.

Apesar de que se esperasse uma associação intensa do jovem pastor à sy̆rinx, essa ligação não foi lembrada em nenhum vaso com representação de pastor. ${ }^{5}$

Por que a ausência da syrinx? A explicação talvez se ligue à afirmação de Amouretti de que, para os pintores de vaso, com os olhos voltados para a cidade, "o pastor não é um tipo humano; é um acessório." (Amouretti 1979) Os amores do jovem pastor músico, tema de interesse literário, sobretudo dos bucólicos como Teócrito e Longus, não interessou aos pintores do séc. V. Com exceção dos pastores da peliké de Paris (Fig. 2) e da ânfora de Berlim (Fig. 2.1), o pastor músico, mesmo devendo ser uma realidade social, é sugerido pela iconografia por meio de personagens míticos, seja Páris com a lýra ou Pã com a syrinx. Observe-se que o único instrumento associado pelos pintores áticos à figura de

(5) Amouretti inclui em seu catálogo do jeune berger musicien a cratera epônima do Pintor de Pã, conservada em Boston, datada de 470-60. Descrevendo a cena da perseguição amorosa de Pã ao jovem pastor, afirma que leva consigo uma sy̆rinx que o identifica como pastor. Na reprodução desse vaso, publicada por Boardman, procuramos insistentemente por essa sy̆rinx, da qual fala Amouretti, mas não a encontramos: enquanto uma mão do jovem está coberta pela pele que usa como manto, na outra segura uma varinha. Cf. Cratera campaniforme. Figuras vermelhas. Pintor de Pã. (ARV2 550/1) Boston, Museum of Fine Arts, 10185. 470-60. Bib.: Amouretti 1979:158-9 (descrição), p. 166-7 (série do tipo jeune berger musicien). Boardman ARFV 1335.1. 
pastores humanos é o aulós. Constata-se aqui uma disjunção entre os testemunhos literário e iconográfico, na medida em que não conhecemos narrativa mítica que associe esse instrumento ao pastoreio. As únicas referências míticas não são propriamente sobre o aulós, mas sobre o monaulós (Aratos "O nascimento de Pã”, ap. Ateneu IV.175f) ou "aulós oblíquo” (Bion Fragmentos e poemas breves VI [Legran]), indicados como instrumentos tocados por Pã associação que deve ter ocorrido em épocas bastante posteriores ao período que estudamos, como exemplifica o tipo escultórico do Fauno ou Pã tocando monaulós, consagrado pela estatuária helenística e romana (Fig. 3).

A literatura antiga, desde os hinos homéricos, liga a sy̆rinx a Pã, associação que foi lembrada por autores do séc. V (Hino homérico a Pã 14-21. Eurípides Electra 699sq; Ion 492sq). ${ }^{6}$ E Pã era sempre lembrado como um deus músico, simbolizando a importância da música no contexto rural, apesar do enorme desinteresse dos pintores por essa temática. No repertório lendário, contava-se que Pã, que tinha um pequeno santuário perto da casa de Píndaro em Tebas, teria cantado um dos seus hinos (Plutarco Moralia 1113b).

A associação da sy̆rinx a Pã, do ponto de vista mítico, tinha sua contrapartida ritualística. A sy̆rinx era o instrumento mais característico dos rituais pastoris, talvez até por ser o instrumento que a maioria dos pastores devia saber tocar e fabricar. Sacrifícios a Pã eram realizados com hinos acompanhados pela sy̆rinx. Mesmo o culto da deusa trácia Áttis, divindade de função pastoril, era realizado com o uso da flauta de Pã (Cf. Longus Pastorais II.31. Ver: Haldane 1966: 105-6). Era comum que camponeses oferecessem

(6) Cf. Antologia grega. Antologia Planudeana (XVI), 12. "Sobre uma estátua de Pã colocada sob uma fonte." (Anônimo); 13. "Sobre uma estátua de Pã colocada sob uma fonte." (Platão, autor ao qual Meleagro atribui três dúzias de epigramas, cuja atribuição é questionada, séc. III a.C. ou anterior) Autores tardios: Antologia grega. Epigramas Votivos (VI), 82. "A Pã." (Paulo Silenciário, ciclo de Agathias, corte de Justiniano, séc. VI); Antologia Planudeana (XVI), 225. "Sobre uma estátua de Pã." (Arabios o Escolástico, época de Justiniano). sua sy̆rinx, num santuário a Pã, como ex-voto (Antologia grega. Epigramas Votivos [VI], 177. "A Pã.” [Teócrito de Siracusa, séc. III a.C.]). Poetas helenísticos cantaram a tristeza da sy̆rinx que jazia muda num templo, ao lugar de estar entretida com o amor - afinal, Pã a inventou como substitutivo de sua amada, a ninfa Syrinx, que o rejeitara (Antologia grega. Epigramas descritivos [IX], 324. “À une syrinx.”). Crenças místicas deviam se associar à flauta de Pã, pois, se os rebanhos escutassem a música sagrada dos seus lábios repousados sobre os caniços, bons ventos soprariam sobre as fazendas e mais leite as vacas produziriam (Antologia grega. Antologia Planudeana [XVI], 17. "Sobre uma estátua de Pã." [Anônimo, Ibycos?]).

A mitologia estabelece o vínculo desse deus com esse instrumento. Filho de Hermes (que

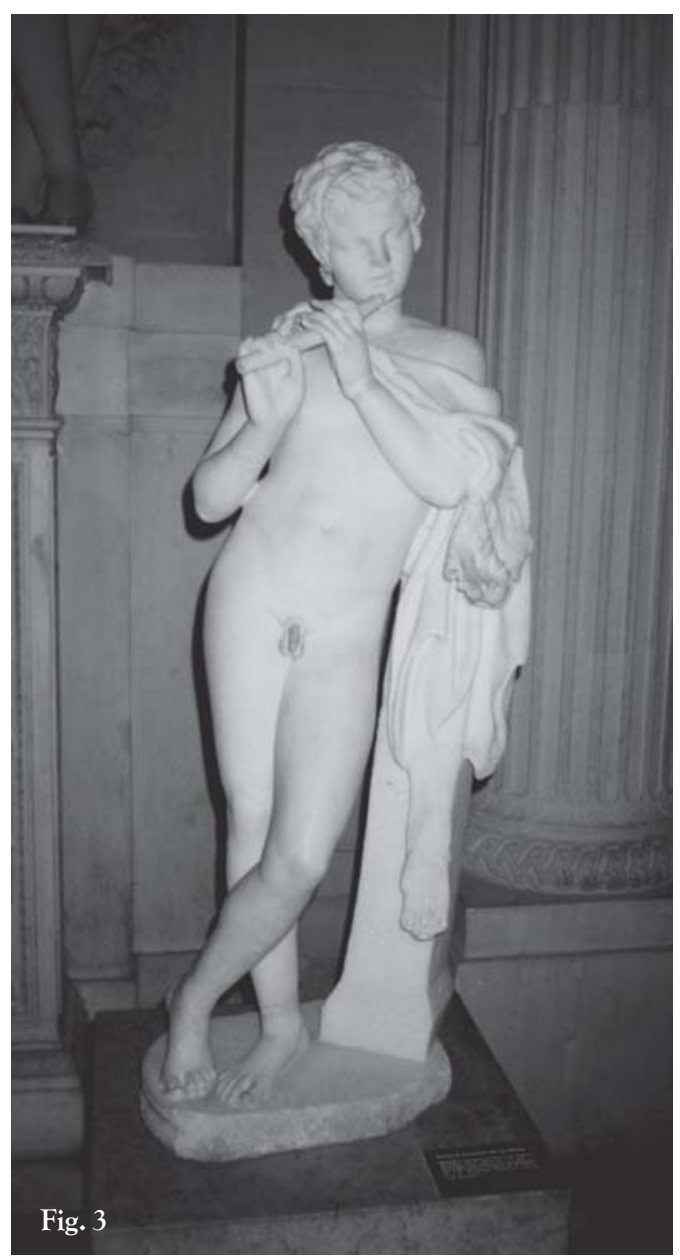


Música e Vida Pastoril na Grécia antiga: o contexto ático segundo evidências arqueológicas, iconográficas e literárias. Revista do Museu de Arqueologia e Etnologia, São Paulo, 18: 199-210, 2008.

também inventou a sy̆rinx, segundo tradição que remonta aos hinos homéricos) com uma ninfa, Pã era uma antiga divindade arcádica que tinha por função garantir a proteção e a multiplicação dos rebanhos. Deus dos bosques e pastos, era cultuado como protetor dos pastores. Sua forma física era uma transição entre a forma animal e a humana: tinha chifres e pernas de bode, além de um rosto feio com fortes traços animais.

Apaixonou-se pela ninfa Sy̆rinx, que o rejeitou devido a seu rosto assustador; esta, pedindo ajuda a seu pai, o rio Ladon, escapou de Pã transformando-se em caniços. Ele se jogou sobre eles e os abraçou, pensando ser sua amada ninfa, e suspirou, e, então, os caniços agitados emitiram um som agradável e queixoso. Comovido com esse som, pegou sete caniços de tamanho desigual, colou-os com cera e criou o instrumento que recebe o nome de sua primeira amada, Syrinx, conhecido também como "flauta de Pã”. Sua música caiu no agrado de todos, até das ninfas, que antes o evitavam e agora o procuram para dançar ao seu redor, ${ }^{7}$ e até mesmo de Baco, que o convidou para participar de seus festejos. Também por sua filiação, tendo Hermes por pai, combinava a dimensão do pastoreio e da música. Lembremos que fora Hermes quem inventara os instrumentos pastoris por excelência, a lýra e a sy̆rinx.

O mito, do mesmo modo, informa como a syrinx foi transmi-

(7) Antologia grega. Antologia Planudeana (XVI), 226. "Sobre uma estátua de Pã." (Alceu, final do séc. III e início do II a.C., contemporâneo de Filipe V da Macedônia.). Antologia grega. Epigramas Descritivos (IX), 823. (Platão; três dúzias de epigramas atribuídos a ele na Coroa de Meleagro, devem se tratar de pastiches, compostos entre 250 e 230 , de textos mais antigos). tida da divindade protetora aos pastores: Pã, apaixonado pelo jovem pastor Dáfnis, ensinoulhe a tocar a sy̆rinx. Dáfnis foi, então, o primeiro entre os mortais a encostar seus lábios nos caniços sagrados, produzindo um "sopro melodioso com os juncos colados com cera" e "modulando canções bucólicas" (Antologia grega. Epigramas descritivos [IX], 433 [Teócrito]; Epigramas Votivos [VI], 177 [Teócrito]. Cf. Antologia grega. Epigramas descritivos [IX], 341). (Fig. 4)

Por intermédio desse conjunto restrito de referências iconográficas, boa parte delas abordando de forma mitológica o tema da música praticada pelos pastores, concluímos que três instrumentos podiam ser usados por eles, a

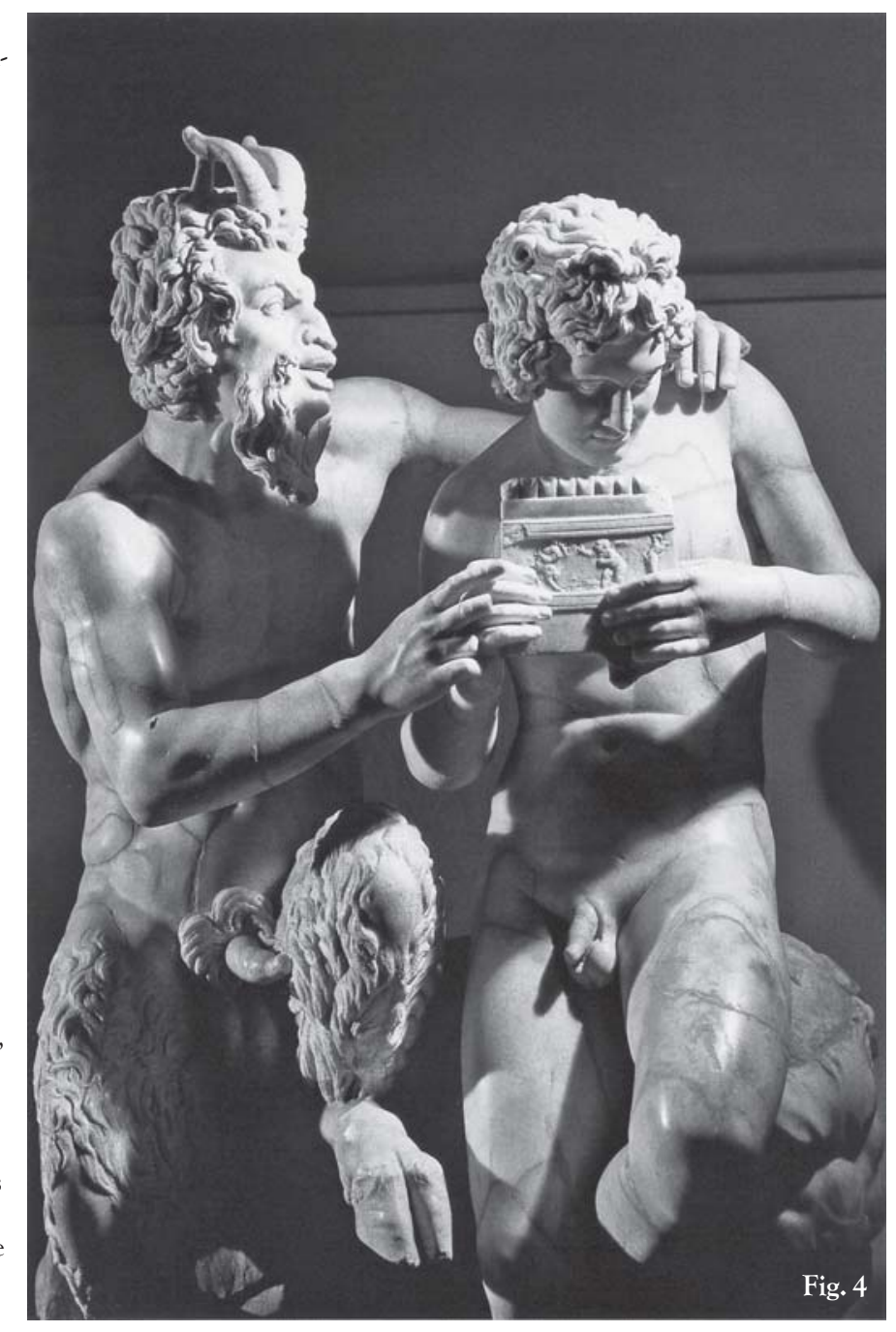


lýra, o aulós e a sy̆rinx, apesar de o último dever ser o mais comum. Todos eles têm em comum o fato de serem instrumentos facilmente fabricáveis de forma rústica e artesanal, sem a necessidade de pagar pelos serviços de um artesão citadino. Syringes e auloí rústicos podiam ser confeccionados com juncos encontrados próximos ao leito de rios e córregos; ${ }^{8}$ a lýra podia ser feita com materiais comuns no dia-a-dia de um pastor: carapaça de tartaruga da montanha (para a caixa de ressonância), chifre (kérata, usado para os braços), couro e tripa de boi (para as cordas e revestimento da caixa) e madeira de sicômoro ou carvalho (para os braços, pécheis, e para a travessa, zugón), além dos kóloppes, substância betuminosa aplicada no ajuste das cordas à travessa superior, utilizada para auxiliar na afinação das mesmas, mecanismo anterior ao desenvolvimento de cravelhas. ${ }^{9}$ Diferentemente dos praticantes de música da cidade, os pastores não freqüentavam escolas, aprendendo de forma autodidata, dada a facilidade dos instrumentos que utilizavam.

\section{Discussão dos dados}

O desinteresse geral que os pintores de vaso, residentes na área urbana ateniense, tinham pelo mundo rural, coloca algumas dificuldades para o uso da iconografia vascular ática para interpretar as interfaces entre a música e o mundo pastoril, dificultando a compreensão das práticas e sentido associado ao uso da música pelos pastores.

No que se refere ao interesse pelo registro das atividades agrárias, verifica-se um descompasso entre os testemunhos literários e as evidências da

(8) Devemos ter consciência de que o aulós de um pastor seria bastante distinto do exemplar sofisticado adquirido por Ismênias ao custo assustador de 7 talentos, o equivalente a 42.000 dracmas, com o que se compravam aproximadamente 700 salpinges do tipo usado no exército. Sobre o uso dos juncos na confecção dos tubos e principalmente das palhetas do aulós, ver: Bélis \& Péché 1996:10-29.

(9) Sobre a fabricação da lýra: Courbin 1980:93-114. Bélis 1985:201-20. iconografia da cerâmica ática. Nos textos clássicos, inclusive a literatura produzida ou consumida em Atenas entre o sexto e o quarto século, constata-se maior interesse pelo mundo rural. É possível que se interponha um ponto de vista de classe social, uma vez que a cerâmica é produzida e pintada por homens vinculados ao artesanato urbano, enquanto a produção dos textos mantém forte vinculação com elites políticas e econômicas com base pronunciadamente agrária. Note-se que a filosofia e a literatura traduzem mais a visão de mundo da elite terratenente, destacando o valor ético do trabalho da terra, ${ }^{10}$ apesar de revelarem preconceito relativamente ao trabalhador da terra, ao campesino. Já entre os pintores de vaso prevalece a visão de mundo de um grupo de trabalhadores ligados ao demos urbano e desvinculado das estruturas agrárias, preterindo temáticas rurais é, ao menos, o que o repertório imagético nos sugere.

É relevante destacar-se que, ao tratarem de temáticas rurais, os pintores de vaso com freqüência optam por abordagens mitológicas, enfoque predominante nas situações em que o acompanhamento musical está registrado, seja na viticultura ou no pastoreio. Evita-se assim uma identificação direta com a rotina de pastores e camponeses, considerados rudes.

Sem sombra de dúvida, a opção pela abordagem mitológica tem suas vantagens, pois aporta uma conotação mística, imbricada na forte vinculação entre o mundo rural e as forças da natureza, interpretadas a partir de uma perspectiva sagrada. Deste modo, alguns personagens mitológicos evocam potências naturais: na viticultura, silenos e mênades; no pastoreio, Pã, faunos e ninfas. De certa forma, funciona também como uma estratégia semântica de se

(10) As fontes escritas revelam um preconceito geral em relação ao trabalho artesanal. Cf. Platão República VI.495d-e.; Leis VIII.846d. Xenofonte Econômico VI.7. Aristóteles (Ps.-) Econômicos I.1343-25. Por outro lado, muitos autores colocam o trabalho da terra como fonte da virtude necessária ao cidadão. Cf. Xenofonte Econômico I.16, 21; IV.2, 24; V.13. Aristóteles (Ps.-) Econômicos, loc. cit. Ver: Vernant 1989:9-33. VidalNaquet 1989:149-76. 
Música e Vida Pastoril na Grécia antiga: o contexto ático segundo evidências arqueológicas, iconográficas e literárias. Revista do Museu de Arqueologia e Etnologia, São Paulo, 18: 199-210, 2008.

posicionar face à estrutura profunda expressa na antinomia cultura versus natureza.

Não obstante o recurso da linguagem mitológica sugira uma conotação predominantemente simbólica deste repertório iconográfico, na representação do espaço e atividades rurais, existe na pintura vascular um processo de referência a aspectos da realidade campesina objetiva. Alguns elementos constitutivos das práticas cotidianas são selecionados e representados de forma idealizada, ao serem incorporados tanto pela imagética mitologizante do mundo rural, quanto por aquela focada nas cenas humanas: um exemplo são os instrumentos musicais utilizados pelos trabalhadores na atividade pastoril, os quais devem retratar uma situação cotidiana objetiva.

Quando analisada à luz de um amplo espectro de fontes literárias e iconográficas provenientes de diferentes suportes, regiões e épocas, a interpretação, destes traços iconográficos indiciais, possibilita uma compreensão mais consistente da música na esfera rural. Esses índices apontam para o emprego alternado da lýra, do aulós, do monaulós e da sy̆rinx no pastoreio. Tudo indica que a syrinx fosse o instrumento mais popular entre os pastores do mundo antigo, uma vez que a lýra, apesar de sua origem rústica, foi apropriada pela cultura intelectual e erudita urbana - sendo ela um instrumento acusticamente limitado em seu volume, podemos deduzir que, na condução dos animais, um pastor preferisse instrumentos de sopro, como o aulós e a sy̆rinx, por serem mais sonoros e mais audíveis no ambiente montanhoso, no qual os ventos, as distâncias e as irregularidades de relevo, poderiam prejudicar o efeito de sua música sobre os animais. No entanto, é verossímil que este pastor preservasse o hábito de tocar a lýra, em suas horas livres, como forma de descanso e lazer, como sugerem fontes textuais e iconográficas de épocas e regiões variadas do mundo grego antigo.

A música, no mundo pastoril, ao mesmo tempo em que visava ao entretenimento, à alegria, ao descanso e ao doce sono, cumpria uma necessidade: auxiliava na comunicação com o rebanho, facilitando sua obediência ao pastor e, concomitantemente, desempenhava uma função mística, ao conquistar a simpatia de Pã, por meio do som sagrado de seus sete caniços colados, propiciando assim benefícios às fazendas e à produção leiteira.

O músico que vivia no campo, como é o caso daquele que se dedicava ao pastoreio, diferia dos tipos urbanos: não era nem o profissional assalariado ou agraciado por prêmios nos festivais, nem tampouco o músico amador culto elogiado por Platão e Aristóteles: era um autodidata rústico, que, além de aprender por meio da tradição e intuição, deveria saber fabricar seu próprio instrumento. $\mathrm{O}$ tom bucólico deste aprendizado, mesmo que desprezado por muitos que nutriam preconceito com relação ao trabalhador rural, nomeadamente aos pastores, foi bastante valorizado em narrativas mítico-poéticas, que conferiam conotação amorosa a esta transmissão de conhecimentos.

A condição de amante e professor de música se sobrepunha nos pares mitológicos homoeróticos: é o que nos contam os poetas sobre Hermes e Ânfion, Pã e Dáfnis, assim como Mársias e Olimpos. Assim, no plano mitológico, foi por meio destas relações amorosas, afinadas com o modelo da pederastia, que a música foi ensinada aos pastores, tornando-se prática corrente na lide rural. Percebe-se aqui a vinculação da música pastoril a outro contexto de significação social, contexto em que se entrelaçam a educação dos cidadãos e o homossexualismo pederasta socialmente aceito.

Enfim, os pastores exerciam a música como parte integrante de sua rotina de trabalho e lazer. Os atores sociais produtores de significação e de testemunhos, como aqueles que nos legaram os textos clássicos e os monumentos figurados, geraram visões variadas sobre a vida dos pastores, umas mais positivas, outras mais negativas, todas, porém, comprometidas com as suas diversas posições na sociedade grega antiga. Muitas destas visões são, de forma indicial, reveladoras de diferentes aspectos de uma vida musical rica e intensa, que deve ter sido um fator distintivo na construção da identidade cultural do homem pastor, o que explicaria a grande admiração por esta música entre poetas gregos de diferentes épocas. 


\section{Documentação iconográfica}

Tema 1: O jovem pastor músico

\section{Personagem mitológico - lýra:}

Figura 1 Hydría. Figuras vermelhas. Pintor da Oinochóe de Yale. (ARV2 503/20) Londres, Museu Britânico, E 178. Em torno de 470. Descrição: Julgamento de Páris. Páris, vestindo clâmide, tocando lýra, sentado sobre base rochosa, ao lado da qual está uma ovelha. Aproximam-se dele Hera, Atena e Afrodite.

Bibliografia: Boardman ARFV 234

Cerqueira 2001:cat. 526.

Comparanda: Figura 1.1 Kýlix. Figuras vermelhas. Makron. Assinada pelo oleiro Hieron. (ARV2 459/4) Berlim, Antikesammlung, F 2291. 490-80. Descrição: Páris, sentado sobre uma superfície rochosa, envolvido por cabras, tocando lýra. Bib.: Amouretti 1979:158, 167. Boardman ARFV 1 310. Cerqueira 2001: cat. 526.1. Figura 1.2 Hydria. Figuras vermelhas. Pintor da Oinochoé de Yale. (ARV² 503/20) Londres, Museu Britânico, E 178. Segundo quartel do séc. V. Descrição: Julgamento de Páris: sentado sobre rochedo, com cabra aos seus pés, enquanto toca lýra, recebe as deusas. Bib.: CVA Museu Britânico 5 (Grã Bretanha 7) III I c, pr. 81.3. Cerqueira 2001: cat. 526.2.

\section{Personagem humano - aulós:}

Figura 2 Peliké. Figuras vermelhas. Pintor de Geras. (ARV2 286/14) Paris, Louvre, G 536 (Campana 823). 480-70.

Descrição: Face A: Jovem pastor, vestindo uma túnica curta, com uma pele de cabra sobre os ombros, semelhante a um manto, e com um gorro de pastor (pîlos), montando um bode, sopra o aulós. $\mathrm{O}$ rosto do animal parece envolvido pela música, tomado por uma doçura expressa na sua boca entreaberta, como se cantasse, qual um personagem de fábula. Face B:

Cena semelhante à anterior. No entanto, o jovem pastor auletés está montando não um bode, mas sim um carneiro.

Bibliografia: CVA Louvre 8 (França 12) III I d, pr. 45.5, 7 e 11. Amouretti 1979:155-
67, fig. à p. 163. Chevitarese 2000, ficha 9; 2001: cat. no 71. Boardman ARFV 1 180. Cerqueira 2001: cat. 525.

Comparanda: Figura 2.2. Ânfora. Figuras vermelhas. Sem atribuição. Berlim, Antikesammlung, F 4052. Século V. Descrição: Jovem pastor, vestindo túnica e pilos, sentado sobre uma rocha, toca aulós diante de um sátiro. Bib.: Amouretti 1979: 167, esp. 167. Cerqueira 2001: cat. 525.1.

Tema 2: Sátiro (Fauno) tocando monaulós

Figura 3 Escultura em mármore. Paris, Museu do

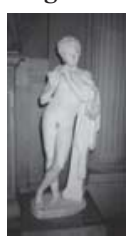
Louvre, Antiga Coleção Borghese, MR 187 (Ma 594). Obra romana do período imperial (séc. I - II d.C.), inspirada em peça que pode ter sido concebida no começo do século III a.C., no estilo da escola dos três grandes mestres do séc. IV a.C., Praxíteles, Scopas e Lysippos.

Tema 3: Pã, em relação amorosa, ensinando a sy̆rinx a um jovem pastor

Figura 4 Grupo escultórico em mármore. Pã e

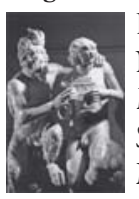
Dafni. Museo Archeologico Nazionale di Napoli, Colezione Farnese, inv. 6329. Bibliografia: Caro, Stefano. Il Gabinetto Segreto del Museo Archeologico Nazionale di Napoli. Guida rapida. Nápoles: Soprintendenza Archeologica di Napoli e Caserna, 2000, p. 10

\section{Agradecimento}

Agradeço, pelas contribuições para este estudo iniciado durante a pesquisa de doutoramento, a orientação de Haiganuch Sarian, as sugestões da co-orientadora Annie Bélis, a troca de idéias com André Leonardo Chevitarese, a estrutura de pesquisa fornecida pela Escola Francesa de Arqueologia de Atenas e pelo Museu de Arqueologia e Etnologia da Universidade de São Paulo, o financiamento da CAPES e o apoio institucional do Departamento de História e Antropologia da Universidade Federal de Pelotas. Os conceitos expostos neste artigo são de responsabilidade restrita de seu autor. 
Música e Vida Pastoril na Grécia antiga: o contexto ático segundo evidências arqueológicas, iconográficas e literárias. Revista do Museu de Arqueologia e Etnologia, São Paulo, 18: 199-210, 2008.

CERQUEIRA, F.V. Music and Pastoral Life in Ancient Greece: The Attic context according to the archaeological, iconographical and literary evidences. Revista do Museu de Arqueologia e Etnologia, São Paulo, 18: 199-210, 2008.

Abstract: This study aims to do a interpretation of the aspects and the meaning of the presence of the musical activity in the shepherd's life in Ancient Greece, particularly in the Attic social and cultural context, through the comparison among the literary, visual and material registers.

Keywords: Ancient Greece - Music - Iconography - Rural.

\section{Referências bibliográficas}

AMOURETTI, M.C.

1979 L'iconographie du berger. Les sources grecques. VIII-III '̇me siècle avant J.C. In: Iconographie et histoire des mentalités. Paris, Ed. de CNRS: $155-67$.

BÉLIS, A.; PÉCHÉ, V.

1996 Du bon usage du roseau. Commentaires sur la fabrication des anches et des tuyaux dans l'Antiquité gréco-romaine. In: Coget, J. (Org.) L'homme, le végétal et la musique. Saint-Joan-de-Milly, FAMDT: 10-29.

BÉLIS, A.

1985 À propos de la construction de la lyre. BCH, 109: 201-20.

\section{BURFORD, A.}

1993 Land and Labor in the Greek World. Col. Ancient Society and History. Baltimore, John Hopkins University Press.

CERQUEIRA, F.V.

2001 Os instrumentos musicais na vida diária da Atenas tardo-arcaica e clássica (540-400 a.C.). O testemunho dos vasos áticos e de textos antigos. 3 vols. Tese de doutoramento. São Paulo, Universidade de São Paulo.

2007 O uso da música no trabalho rural na Antigüidade clássica: o caso do aulós na vindima. Métis, Caxias do Sul, Universidade de Caxias do Sul, 6: 243-257.
CHEVITARESE, A.L.

2000-2001 Pastores e trabalhadores agrícolas na Ática nos períodos arcaico e clássico. Classica, Belo Horizonte, Sociedade Brasileira de Estudos Clássicos, 13-14: 123-144.

2001 O espaço rural da pólis grega. O caso ateniense no período clássico. Rio de Janeiro, Fábrica de Livros / SENAI.

COURBIN, P.

1980 Les lyres d'Argos. BCH Suppl. VI (Études Argiens): 93-114.

GERNET, L.

1982 Droit et ville dans l'Antiquité grecque. In: Gernet, L. Droits et institutions en Grèce antique. Paris: Flammarion (1968): 266-78.

HALDANE, J.A.

1966 Musical Instruments in Greek Worship. Greece and Rome, 13: 98-107.

VERNANT, J.P.

1989 Trabalho e natureza na Grécia antiga. In: Vernant, J.P.; Naquet, P.-V. Trabalho e escravidão na Grécia Antiga. Campinas, Papirus: 9-33.

VIDAL-NAQUET, P.

1989 O estudo de uma ambigüidade: os artesãos na cidade platônica. In: Vernant, J.P.; Naquet, P.-V. Trabalho e escravidão na Grécia Antiga. Campinas, Papirus: 149-76. 